\section{INVESTMENT IN FIXED ASSETS IMPACT ON THE EMPLOYMENT GROWTH IN THE REPUBLIC OF SERBIA}

\section{INTRODUCTION}

Within a country or a nation, economic growth is commonly related to investments. Investing involves the purchase of assets with the intent of holding them for the long term. When companies and other entities engage in sound business investment practices, it typically results in economic growth. An investment is an asset or item acquired to generate income or appreciation. (5)

One aspect of the dynamics of the Serbian economy is the dynamics of growth of the book value of fixed assets of all companies in the country and the number of employees in these companies.

The primary data on fixed asset values are available in the companies' financial statements. Book value of fixed assets comprises intangible assets; immovables (property), plant and equipment; biological assets; long-term financial investments; and long-term receivables. In writing this work, we assume that the total fixed assets are devoted to production (2, 9-13). For accounting purposes, assets do not include human capital, although it should be a key driver for an investor's portfolio needs.

The Law on Accounting of 2013 contributed to harmonizing financial reporting rules and principles with the European Union acquis, among others introducing a readjustment of accounting rules to the level of economic activity and size of legal entities, a new system of financial reporting, and full transparency of financial statements. The Serbian Business Registers Agency provides full transparency of financial statements by publishing the aggregate data for

DOI:

\section{SUMMARY}

Key words: Average annual investment in fixed assets, average annuala increse in the number of employees, cost of job creation.

This study focused on the effect of investments in fixed assets on the employment growth in Serbia during the period from 2013 to 2020 . The data are drawn from the publicly availably data of the Serbian Business Register Agency and include all registered companies in the country which submitted their annual reports. The results show the high correlation between yearly investment in fixed assets and employment growth. We also concluded that the average annual investment in fixed assets grows from year to year, making the opening of a new workplace each year more expensive.

Dr Jozefina Beke-Trivunac, redovni profesor, ALFA BK Univerzitet, Beograd, e-mail: jozefina.beke@live.com

Mr Bojan Stoiljković, Asistent, Doktorand, ALFA BK University, Beograd,

Dr Drinka Peković, docent, ALFA BK Univerzitet, Beograd, 
statistical and other purposes and by publishing individual annual financial statements with the required documents on its website. The statistics maintained by the Agency APR track the universe of active firms and its subset of active firms which submitted their financial reports and include annual observations beginning in 2014 and currently runs through 2020. It provides detailed industry, location, and employment information for every establishment in a nationally comprehensive and integrated manner.

This study aims to determine the effect of the growth of fixed assets book value on the employment growth during the period from 2014 to 2020 in Serbia. In general, fixed assets are financed by long-term financial capital (equity and long-term liabilities, like long-term loans, bonds, and similar sources of long-term funds). On average, during the selected period in Serbia, about $90 \%$ of long-term liabilities are invested in longterm assets, and the rest $10 \%$ in current assets.

Investments in fixed assets are one of the basic ways to increase production and employment. However, there are different views in the literature regarding the incentive effects of fixed assets investment on employment, as well as the extent of these effects. Some research studies show that the impact of fixed assets investment on employment varies significantly across sectors of production. In agricultural production, investments in fixed assets contribute to the improvement of agriculture technology but reduce the need for labour. A much larger effect on employment is present in industries with a high share of capital technology. The results of the research study by Fanhui Fan and Li Jing (4, 955) show a high positive correlation between investments in fixed assets and industrial employment (correlation coefficient is 0.883) while the correlation between fixed assets investment in agricultural production and agricultural employment is negative and low (correlation coefficient is 0.377 ).

A prerequisite for investments in fixed assets is long-term finance. The firms with long-term finance not only invest more in fixed assets and increase employment, but also the quality of the created jobs is higher. A survey conducted at the firm level in 73 low- and middle-income countries shows that the probability of increasing employment is larger by 0.77 percentage points in firms with increasing fixed assets investments and long-term finance. In addition, these firms are more likely to employ permanent employees (for 0.99 percentage points) and invest in the training of production workers (for 2.4 percentage points) than the firms with short-term finance and small fixed assets investments $(10,16-18,22)$. It can be concluded that fixed assets investments contribute not only to employment growth but also to job quality improvement. Similar results were ob- 
tained by Ayyagari et. al. $(1,4)$ researching access to finance for small and medium firms in developing countries, which is needed for fixed assets investment, and job growth. Firms with access to loan are more likely to increase employment by 1 to 3 percentage points than firms with no access to finance.

The research studies of the fixed assets investment impact on employment are relatively scarce. However, based on the current research results, we can conclude that the effects of investments in fixed assets on employment are multiple and complex (3).

\section{MATERIALS AND METHODS}

To determine the effect of fixed assets book value on the employment growth, we drawn the data from the Financial Statements Annual Bulletin published by the Serbian Business Registers Agency. All data represent aggregated data of all enterprises which submitted their financial reports, according to the Law on Accounting from 2013. The data set spans the period from 2013 to 2020.

The selected data include the number of employees, the value of permanent assets at the end of each year, and depreciation and amortization.

We analyzed the data both in Excel and SPSS statistical programs. Each step of analysis is presented in the next section in detail.

All financial data are presented in the thousand Serbian dinars.

We are aware of the limited time series of analyzed data. We also believe that the accounting information of presented book values is fair enough for this analysis.

\section{RESULTS AND DISCUSSION}

The initial overview of financial data of book value of fixed assets and the number of employees (Table 1) reveals the continual increase of the value of the fixed assets and the number of employees in the Serbian economy,

Table 1: Book value of fixed assets and the Number of employees - statistical data

\begin{tabular}{lrrrrrrrr}
\hline & \multicolumn{1}{c}{$\mathbf{2 0 1 3}$} & \multicolumn{1}{c}{$\mathbf{2 0 1 4}$} & \multicolumn{1}{c}{$\mathbf{2 0 1 5}$} & \multicolumn{1}{c}{$\mathbf{2 0 1 6}$} & \multicolumn{1}{c}{$\mathbf{2 0 1 7}$} & \multicolumn{1}{c}{$\mathbf{2 0 1 8}$} & $\mathbf{2 0 1 9}$ & $\mathbf{2 0 2 0}$ \\
\hline Number of enterprises & 95.907 & 93.759 & 94.656 & 97.543 & 104.216 & 103.995 & 106.033 & 106.111 \\
Number of employees & 944.900 & 976.061 & 990.900 & 1.036 .057 & 1.081 .107 & 1.131 .227 & 1.174 .362 & 1.217 .954 \\
\hline $\begin{array}{l}\text { Fixed assets value } \\
\text { (Dinars 000) }\end{array}$ & 7.290 .330 .772 & 7.531 .979 .342 & 7.650 .055 .733 & 8.004 .262 .417 & 8.455 .179 .210 & 8.861 .605 .501 & 9.651 .472 .758 & 10.118 .710 .847 \\
\hline
\end{tabular}


The investment in fixed assets naturally contributes to the increase in the number of employees. Our interest was aimed at the two questions:

1. The level of correlation of the fixed assets grow and the increase of the number of employees;

2. The movements of average annual increase of fixed assets by the new employee.

\section{The relationship between fixed assets and the number of employees}

A simple analysis in Excel reveals the high correlation coefficient (0.0875) between the book value of fixed assets and the Number of employees. The coefficient of determination is already very high, showing that the increase of investments in fixed assets contributes to the increase in the Number of employees by 0.9746 .
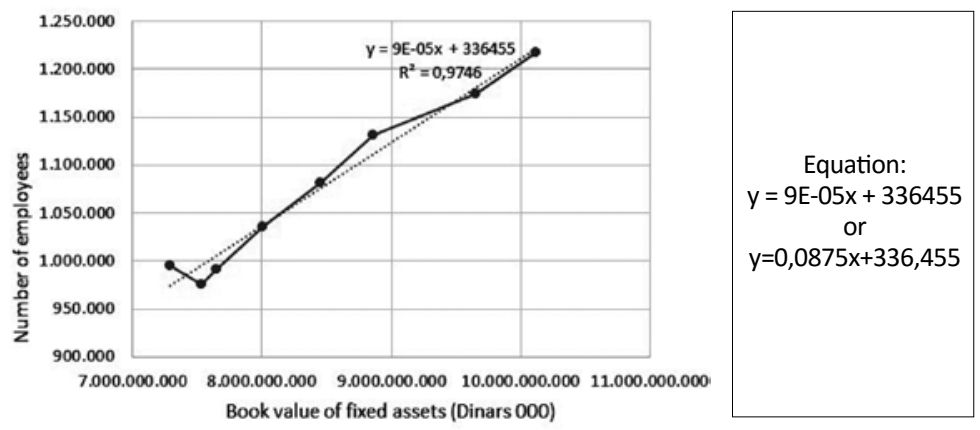

Figure 1: The ratio of Fixed assets book value and the Number of employees

Additional statistics is done in SPSS statistical program, as follows:

In order to determine the existence of a linear relationship between the variables number of employees (Number_of_employees) and fixed assets (Fixed_property), a scatter plot diagram of these two variables was used. Based on the scatter plot, the conclusion is that there is a linear relationship between these two variables.

The arithmetic mean of the number of employees is 1075321, while the standard deviation is 91261.71 . The coefficient of variation is $8.49 \%$. We conclude that the arithmetic mean of the age is an indicator of the central tendency and that the data are satisfactorily grouped around it.

The average value of fixed assets (expressed in 000 dinars) is 8445449572.50, while the standard deviation is 1029812771.52. 


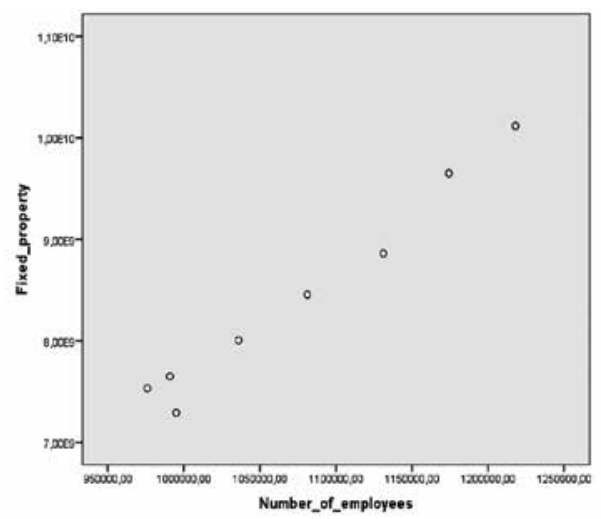

Figure 2: Scatter plot of variables Number of employees and fixed assets

The coefficient of variation is $12.19 \%$ and satisfactory representS the arithmetic mean.

The table below shows the values of the arithmetic mean and standard deviation of the variables we examine.

Table 2: Descriptive Statistics

\begin{tabular}{lcrc}
\hline & Mean & Std. Deviation & N \\
\hline Number_of_employees & 1075321,0000 & 91261,71375 & 8 \\
\hline Fixed_assets & 8445449572,5000 & 1029812771,52330 & 8 \\
\hline
\end{tabular}

Pearson's correlation coefficient equals 0.987 . We conclude that there is a high positive linear correlation between the two variables number of employees and fixed assets. Based on the value Sig. $=0.000$, we conclude that the obtained correlation coefficient is statistically significant for the significance level of 0.01 . The calculated coefficient of correlation is presented in the following table:

Table 3: Correlations between the number of employees and the fixed assets

\begin{tabular}{llcc}
\hline & & $\begin{array}{c}\text { Number_of } \\
\text { _employees }\end{array}$ & Fixed_assets \\
\hline Number_of_employees & Sig. (2-tailed) & 1 &, $987^{* *}$ \\
& $\mathrm{~N}$ & 8 &, 000 \\
& Pearson Correlation &, $987^{* *}$ & 8 \\
Fixed_assets & Sig. (2-tailed) &, 000 & 1 \\
& $\mathrm{~N}$ & 8 & 8 \\
\hline & $* *$ Correlation is significant at the 0.01 level (2-tailed).
\end{tabular}




\section{The relationship between the annual increase of fixed assets and an annual increase of the Number of employees}

To analyze this relationship, we calculated the annual increase of fixed assets combining the date of fixed assets value at the beginning and at the end of the period stated in the balance sheets and the amount of depreciation and amortization stated in the income statements, as follows:

Table 4: Annual movements of the fixed assets value

\begin{tabular}{lcrrrrrr}
\hline \multicolumn{1}{c}{ (Dinars 000) } & \multicolumn{1}{c}{$\mathbf{2 0 1 4}$} & $\mathbf{2 0 1 5}$ & $\mathbf{2 0 1 6}$ & $\mathbf{2 0 1 7}$ & $\mathbf{2 0 1 8}$ & $\mathbf{2 0 1 9}$ & $\mathbf{2 0 2 0}$ \\
\hline Opening balance & 7.290 .330 .772 & 7.531 .979 .342 & 7.650 .055 .733 & 8.004 .62 .417 & 8.455 .179 .210 & 8.861 .605 .501 & 9.651 .472 .758 \\
Increase (calculated)* & 549.596 .648 & 422.997 .228 & 696.102 .417 & 819.087 .074 & 796.934 .592 & 1.238 .128 .173 & 945.471 .967 \\
Depreciation and amortization & 307.948 .078 & 304.920 .837 & 341.895 .733 & 368.170 .281 & 390.508 .301 & 448.260 .916 & 478.233 .878 \\
Closing balance & 7.531 .979 .342 & 7.650 .055 .733 & 8.004 .262 .417 & 8.455 .179 .210 & 8.861 .605 .501 & 9.651 .472 .758 & 10.118 .710 .847 \\
\hline \% of the increase & $7,5 \%$ & $5,6 \%$ & $9,1 \%$ & $10,2 \%$ & $9,4 \%$ & $14,0 \%$ & $9,8 \%$ \\
\hline
\end{tabular}

*Net increase in fixed assets value is calculated as the difference among opening and the closing balance and the depreciation and amortization value for the year (opening balance less depreciation less closing balance).

By dividing the increase of fixed assets value by increasing the number of employees for the year, we calculated the average investment in fixed asset book value per one worker. As presented on the following figure, the average investments of fixed assets per worker continually increase.

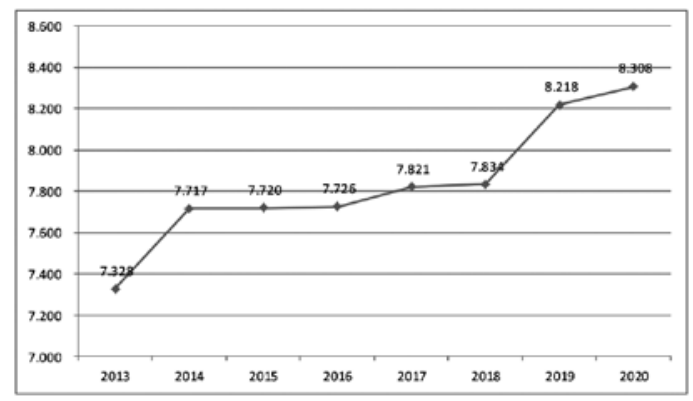

Figure 3: Average fixed assets by the employee in Dinars 000 (The value of fixed assets divided by the Number of employees)

The initial assumption is that the new investments per worker continually increases and make each new workplace more and more expensive. 


\section{CONCLUDING REMARKS}

This paper marks a first attempt to empirically address the relationship between investment in fixed assets and the employment growth in Serbia during the period from 2013 to 2020. The current paper serves as an initial step highlighting an important elementary relationship for understanding economic dynamics in Serbia.

The book value of fixed assets in the balance sheet of all companies in Serbia and the corresponding number of employees has increased in recent years. Business dynamism, as measured by these new investments in fixed assets, has increased.

The high correlation of these two trends indicates the new investments in fixed assets as the most significant generator of the number of employees.

The average value of investments in fixed assets by the employee also increases from year to year and makes the opening of the new workplace more expensive.

\section{BIBLIOGRAPHY}

1. Ayyagari, M., Juarros, P., Peria, M., Singh, S. (2016). Access to Finance and Job Growth: Firm- Level Evidence across Developing Countries, Policy Research Working Paper No. 7604, World Bank Group.

2. Damodaran, Aswath (2007) Return on Capital (ROC), Return on Invested Capital (ROIC) and Return on Equity (ROE): Measurement and Implications, Stern School of Business, July 2007. Available at: returnmeasures (nyu.edu). Retrieved on June 6, 2021. 2

3. Decker, R., Haltiwanger, J., Ron Jarmin, R. and Miranda, J. (2014) The Role of Entrepreneurship in US Job Creation and Economic Dynamism, Journal of Economic Perspectives-Volume 28, Number 3-Summer 2014-Pages 3-24.

4. Fan, F., Jing, L. (2011). Study of Fixed Assets Investment's Effect on the Employment of Three Industries, Proceedings of the $7^{\text {th }}$ International Conference of Innovation \& Management,951-956. https:// www.pucsp.br/icim/ingles/downloads/papers_2010/part_5/58 Study\%20of\%20Fixed\%20Assets\%20Investment_s\%20Effect\% $2 \overline{0}$ on\%20the\%20Employment\%20of.pdf

5. Investment. (n.d.). Available at: http://www.investopedia.com/ terms/i/investment.asp. Retrieved on June 5, 2021. 1

6. Serbian Business Registers Agency, Financial Statements Annual Bulletin 2020, Belgrade, April 2021. 3

7. Serbian Business Registers Agency, Financial Statements Annual Bulletin 2018, Belgrade, April 2019. 4

8. Serbian Business Registers Agency, Financial Statements Annual Bulletin 2016, Belgrade, April 2017. 5

9. Serbian Business Registers Agency, Financial Statements Annual Bulletin 2014, Belgrade, July 2015. 6

10. Sommer, C. (2021). The impact of patient capital on job quality, investments and firm performance: Cross-country evidence on longterm finance, Discussion Paper No. 6/2021, Deutsches Institut für Entwicklungspolitik (DIE), Bonn.
UČINAK ULAGANJA U STALNU IMOVINU NA RAST ZAPOSLENOSTI U REPUBLICI SRBIJI REZIME

Ključne reči: Prosečno godišnje ulaganje u stalna sredstva, prosečno godišnje povećanje broja zaposlenih, cena novog radnog mesta.

Ovaj rad bavi se efektom ulaganja u osnovna sredstva na rast zaposlenosti u Srbiji u periodu od 2013. do 2020. Podaci su preuzeti iz javno dostupnih podataka Agencije za privredne registre Srbije i uključuju sve registrovane kompanije $u$ zemlji koje su podnele svoje godišnje finansijske izveštaji. Rezultati pokazuju visoku korelaciju između godišnjeg ulaganja u osnovna sredstva i rasta zaposlenosti. Takođe smo zaključili da prosečna godišnja ulaganja u osnovna sredstva rastu iz godine u godinu, čineći otvaranje novog radnog mesta svake godine sve skupljim. 